\title{
The Role of Counseling to Cocoa Farmer Groups in Soppeng Regency
}

\author{
Asti Astari' ${ }^{1}$, Sitti Bulkis², Kaimuddin², Laode Asrul'2, Darmawan Salman², Mahyuddin² \\ ${ }^{1}$ Agribusiness Study Program, Graduate School Hasanuddin University, Makassar, Indonesia \\ ${ }^{2}$ Lecturer of Agribusiness Program, Postgraduate School, Hasanuddin University, Makassar, Indonesia
}

Correspondence Author: Asti Astari, Agribusiness Study Program Students, Postgraduate School of Hasanuddin University, Indonesia

Email: astyastari.xiiac.ict@gmail.com, astiastari@pasca.unhas.ac.id

Received date: 28 August 2019, Accepted date: 2 December 2019, Online date: 20 December 2019

Copyright: (C) 2019 Asti Astari et al., This is an open-access article distributed under the terms of the Creative Commons Attribution License, which permits unrestricted use, distribution, and reproduction in any medium, provided the original author and source are credited.

\begin{abstract}
The purpose of this study was to analyze the role of counseling to cocoa farmer groups. This study used a qualitative research approach. Sampling in this study was conducted purposively consisting of 70 cocoa farmers. The sample in this study was the cocoa farmers who participated in the counseling of farmer group program conducted in Soppeng, South Sulawesi province. Data collection techniques were done by interview, observation and documentation study. Data were analyzed using qualitative descriptive analysis. The results showed that the role of counseling of cocoa farmer groups in Soppeng District consisted of, (a) At the stage of awareness and formation of conscious behavior, farmers do not realize that advising programs can provide benefits for them; (b) In the ability transformation stage, farmers have not been able to absorb all the learning that has been given by the counselor; and (c) At the stage of increasing intellectual and skills, intellectual abilities and skills of farmers are not yet optimal. The roles of counseling of cocoa farmer groups are not optimal.
\end{abstract}

Keywords: cocoa agribusiness, farmer groups, the role of counseling.

\section{INTRODUCTION}

Cocoa (Theobroma cacao L.) is a plantation commodity that has a vital role for the national economy, especially as a provider of employment, a source of income and foreign exchange. In 2017, cocoa contributed the third largest foreign exchange contribution to the plantation sub-sector after rubber and palm oil with a value of US \$1.05 billion [1].

Based on BPS data (2018), there are four provinces of cocoa production centers in Sulawesi, namely Central Sulawesi with a contribution of $19.37 \%$ to national cocoa production, then Southeast Sulawesi with a donation of $16.29 \%$, South Sulawesi with a contribution of $16.28 \%$ and West Sulawesi with $9.78 \%$ contribution. These four provinces contributed $61.725 \%$ of Indonesia's total cocoa production. South Sulawesi as a province where the national cocoa production has decreased in production in a few years. Based on BPS data, the value of South Sulawesi cocoa exports as of August 2017 amounted to US \$ 47.09 million. In fact, in the same period last year, South Sulawesi recorded an export value of US \$97.48 million for cocoa. The value of cocoa exports decreased to 51.7 percent [2].

One area where cocoa production has not increased is Soppeng Regency. Even though Soppeng Regency is one of the regions with superior commodities in the plantation sector, namely cocoa. Following are the data of cocoa production in Soppeng Regency:

Table 1. Cocoa Production (2014-2017)

\begin{tabular}{ccc}
\hline No. & Year & Amount of Production \\
\hline 1. & 2014 & $11.576,55$ ton \\
\hline 2. & 2015 & $12.345,39$ ton \\
\hline 3. & 2016 & $12.361,39$ ton \\
\hline 4. & 2017 & $12.361,32$ ton \\
\hline
\end{tabular}

Source: BPS of Soppeng Regency, 2018

Based on table 1, cocoa production increased from year to year, but from 2016 to 2017, cocoa production did not increase. The amount of cocoa production can be influenced by the role of human resources in managing their farming [3]. 
Agricultural development, specifically for cocoa agribusiness development, is determined by its human resources. If human resources have high motivation, creativity and the ability to develop innovatively, then agricultural development can be better. Therefore farmers need to be counsel to improve the ability of human resources. Counseling means an increase in capability that has potential. Starting from the status of the less empowered to become more empowered, so it is more responsible [4].

In developing cocoa agribusiness, the goals of counseling are better farming, better business, and better living. Farmers who are the main actors in agricultural development in Indonesia are generally classified as a weak economy, which is weak in terms of capital, knowledge, and application of technology, and often also less motivated to move forward [5].

The factors that have a relationship cocoa farm receipts, namely: motivation, land area, the amount of production, household income, farmers' attention to the cocoa crop, perception, experience, ability to accept risks, savings ability, the response of farmers to farmers developed and the price level. In formulating policies for agricultural development, particularly cocoa plantation investment policy of the people's cacao farm should pay attention to the farmer's economic aspects because dominant factors related to the size of reinvestment by the farmers is the commercial aspect. [6]

The farmer's characteristics (age, educational level, farming experience, not related to the choice of adaptation strategy, while the number of family dependents and role of advisor was associated with the choice of adaptation strategy. [7] Access cooperative farmers and extension agents can increase the productivity of farmers. [8] Method of participatory training intervention through learning by the doing method can become an economics machine for improvement of farmer's income. [9] The implication was local government especially should give more extension to farmers. [10]

Based on the very complex problems often faced by farmers, the main problem occurs because the ability of human resources in managing farming is not optimal and maximizes their potential. Therefore, the government is trying to deal with the problem by providing various counseling programs through agribusiness development.

\section{METHODOLOGY}

This research uses a descriptive qualitative research approach. A qualitative approach is used to collect data and information as ultimately as possible by describing the role of advising groups of cocoa farmers in developing cocoa agribusiness in Soppeng District. This research held from September to October in Soppeng Regency. Sampling in this study was done by purposive sampling consisting of 70 cocoa farmers. The sample in this study was the cocoa farmers who participated in the farmer group counseling program conducted in Soppeng District. Data collection techniques are done by interview, observation and documentation study. Data collected were analyzed through data reduction, data presentation and making conclusions.

\section{RESULTS AND DISCUSSION}

The cocoa farmer group counseling activities in Soppeng Regency consist of training and guidance activities which include the development of superior seedlings, good cocoa cultivation field schools and integrated pest control, training programs and technology operation guidance, cocoa processing training programs and group dynamics training programs. The activity was attended by farmers and accompanied by staff from the Soppeng District Plantation Office and counselors.

The counseling activities implemented in the process of counseling farmer groups begin with the counseling program planning for several times, then the farmers do their own practice according to the instructions during the training activities based on their own abilities, desires, and needs. Besides, farmers who are given training must be included in farmer groups. Before farmers receive training activities, the counselor and staff from the Soppeng District Plantation Office inform the farmers about the counseling program that will be implemented. Farmers who want to take part in an empowerment program must join a farmer group by submitting the RDKK which is assisted by counselors and staff from the Soppeng District Plantation Office.

The stages of the counseling process are divided into several approaches, starting from the personal approach to the mass approach. This process began with awareness, training, and assistance as implemented by the counselor and staff of the Soppeng District Plantation Office. In accordance with the opinion by Sulistyani (2014), that "The stages that must be passed in the process of empowering farmer groups include: (a) The stage of awareness-raising and the formation of conscious behavior; (b) The capability transformation stage consists of knowledge insights, their skills are added insight and provide basic skills so that they can take part in development; and (c) The stage of increasing intellectual abilities, skills so that innovative initiatives and abilities are formed to deliver independence. [11]

The first stage is the stage of awareness and formation of conscious behavior. At the awareness, the stage is the preparation stage in the process of counseling farmer groups. At this stage, the counselor as a person who empowers farmers provides a touch of awareness that will show the desire and recognition of their farmer groups. Awareness activities for farmer groups can stimulate their awareness that they need improvement in the group so that they can create a better future. Likewise with the awareness process on the counseling program of farmers groups in Soppeng Regency, where the counselor and staff of the Soppeng District Plantation Office jointly held a socialization and counseling activity for cocoa farmers in Soppeng Regency regarding the counseling program to be held. The enthusiasm of cocoa farmers in participating in counseling activities is still lacking, as seen from the percentage of farmers who attend below $50 \%$ of all members of farmer groups.

This counseling activity aims to increase awareness and at the same time introduce the program. As Mosher's statement (1966), which states that agricultural counseling is only a "connecting factor", the counselor as a bridge between the Soppeng District Plantation Office as a provider of counseling programs while farmers as targets of counseling programs. Extension 
officers are also required to play an active role in inviting farmers to participate in every activity held by the Soppeng District Plantation Office. [12]

The second stage is the stage of transformation of abilities and knowledge, skills so that their insights increase and provide necessary skills so they can take a role in development. Capability transformation stage in the cocoa farmer group counseling program in Soppeng Regency includes the growth of superior seedlings through top grafting, good cocoa cultivation field schools and integrated pest control, training programs and guidance on the operation of appropriate plantation technology, cocoa processing training programs and dynamic training programs group. The counselor only supervises and assists farmers to apply the lessons learned during the counseling activities. Extension officers manage and assist only about 1 to 2 times a month and only supervise through the head of the farmer group.

The third stage is the stage of increasing intellectual abilities and skills to form initiatives and innovative capabilities to achieve the independence of cocoa farmer groups in Soppeng Regency. This stage is the stage of expanding the intellect and skills needed by farmers to be more independent. In the activity of counseling cocoa farmer groups, farmers are not only given learning but also given assistance in the form of seeds and equipment that will be used by farmers. The counselor only conducts coaching when counseling activities are held. Several times the counselor visited the farm and farmer's house.

Increasing the understanding of cocoa farmers regarding the materials provided during counseling activities and practices in applying the material is a form of independence in the empowerment of farmer groups. Community counseling is an effort to increase capability and increase community independence. In line with that, counseling can be interpreted as an effort to increase the ability of the community to participate, negotiate, influence and control the community institutions responsibly for a better life. Therefore, through the participation of farmers who are members of farmer groups for the counseling of cocoa farmer groups, the main capital is the success of the farmer group counseling program to improve the welfare of cocoa farmers in Soppeng Regency.

Cocoa farmers are directed to understand that this counseling activity is an activity to increase the productivity and income of farmers. Increasing the independence of farmers with a farmer group counseling program as expressed by Sulistiyani (2004) that, "the goal to be achieved from counseling is to make individuals and communities independent. This independence includes the independence of thinking, acting, and controlling what they do. To be independent, we need to support the ability of human resources that are intact with cognitive, conative, psychometric and affective conditions as well as other physical material resources." [11]

Increased independence of farmers is characterized by increased knowledge, attitudes, and skills. Increased culture from cocoa farmers is changing knowledge about cocoa cultivation techniques and integrated pest control. Increased attitudes of cocoa farmers are changes in positions that were initially passive because they considered the counseling program organized by the Soppeng District Plantation Service as having no benefit for farmers to be actively participating in the counseling program and practicing according to the lessons learned in the counseling program. Enhancing the skills of cocoa farmers is increasing their skills in cocoa farming which, based on their own experience, becomes skills that are in accordance with good cocoa cultivation techniques.

Based on the results of the study, cocoa farmer groups in Soppeng District have increased knowledge and skills. However, the attitude of cocoa farmers in the Soppeng Regency towards the counseling program is still low. Most farmers feel that the counseling program provided does not benefit them; besides cocoa farmers in Soppeng Regency are afraid to take risks from changes in their farming.

\section{CONCLUSION}

Based on the results of research on the counseling process of cocoa farmer groups in Soppeng Regency are not optimal, it can be concluded several things, namely:

a. At the stage of awareness and formation of conscious behavior, farmers do not realize that counseling programs can provide benefits for them.

b. In the ability transformation stage, farmers have not been able to absorb all the learning that has been given by the counselor.

c. At the stage of increasing intellectual and skills, mental abilities and skills of farmers are not yet optimal.

\section{REFERENCES}

[1] BPS, 2017. Kabupaten Soppeng dalam Angka Tahun 2017.

[2] BPS, 2018. Kabupaten Soppeng dalam Angka Tahun 2018.

[3] Dinas Perkebunan Kabupaten Soppeng, 2017

[4] Sukino, 2013. Membangun Pertanian dengan Pemberdayaan Masyarakat Tani, Yogyakarta: Pustaka Baru Press.

[5] Mardikanto, Totok dan Soebianto, Poerwoko. 2009. Pemberdayaan Masyarakat dalam Perspektif Kebijakan Publik. Bandung: CV Alfabeta.

[6] Syamsinar, Amal, Sitti Nurani Sirajuddin. 2015. Analysis of Factors Associated with the Size of Receipt Reinvestment Cocoa Farming. American-Eurasian Journal of Sustainable Agriculture ISSN: 1995-0748, EISSN: 1998-1074 2015, volume (9), issue (4): pages (8-14)

[7] A. Amidah Amrawaty, Ikrar M. Saleh, Jamila. Relationship of Farmer's Characteristics with Adapted Choice in Facing of the Lack Feeding in Barru Regency. AENSI Journals Advances in Environmental Biology ISSN-1995-0756 EISSN-19981066. Advances in Environmental Biology, 11(12) December 2017, Pages: 21-25 
[8] Tanri Giling Rasyid, Syamsuddin Hasan, Sjamsuddin Rasjid and Sitti Nurani Sirajuddin. Accessibility goat livestock cooperation with the government, merchant banking and collecting in Majene regency, West Sulawesi Province. AmericanEurasian Journal of Sustainable Agriculture ISSN: 1995-0748, EISSN: 1998-1074 2015, volume(9), issue(7): pages(13-18)

[9] Tanri Giling Rasyid, Syamsuddin Hasan, Sjamsuddin Rasjid and Sitti Nurani Sirajuddin. Development model of goat farming business base on productive economy in Majene regency, West Sulawesi, Indonesia. American-Eurasian Journal of Sustainable Agriculture (Vol. 10, Issue 3)

[10] Veronica Sri Lestari, Sitti Nurani Sirajuddin, Kasmiyati Kasyim. Perception of Beef Cattle Farmers toward Biosecurity Practices. AENSI Journals ces in Environmental Biology ISSN-1995-0756 EISSN-1998-1066. Volume 9 (24) November 2015, Pages: 450-452

[11]Sulistiyani, Ambar Teguh. 2004. Kemitraan dan Model-Model Pemberdayaan. Yogyakarta: Gava Media

[12]Mosher.A.T, Menggerakkan Dan Membangun Pertanian, Jakarta : C.V. Yasaguna 1966. 